PiJIES: Pedagogik Journal of Islamic Elementary School April 2018, Vol.1, No.1, hal. 57-72

ISSN(P): 2356-1483; ISSN(E): 2615-3904

C 2018 PGMI IAIN Palopo. http:// ejournal-iainpalopo.ac.id/ PiJIES

\title{
PENINGKATAN KETERAMPILAN MENULIS KARANGAN DESKRIPSI DENGAN MENGGUNAKAN MEDIA GAMBAR
}

\author{
Idarliati \\ Institut Agama Islam Negeri Palopo \\ Jl. Agatis Balandai Kota Palopo, 91914 \\ E-mail: idar.idarliati@email.com
}

\begin{abstract}
The aim of this research was to find out the improvement of writing essay writing skills that were applied through the image media to the fifth-grade students of SDN 09 Mattekko kec. Bara City of Palopo. This study uses a quantitative and qualitative approach with a type of Classroom Action Research (CAR) designed through three cycles. The subject of the research was Mattekko 09 Elementary School Elementary School students, amounting to 24 students. Data collection techniques used are observation, documentation, and tests. Data obtained were analyzed using a descriptive statistical formula (percentage) to describe descriptively the results of the study. Furthermore, to discuss and explain the results of research that are qualitative descriptive, the data reduction analysis, data presentation, and conclusion drawing techniques are used. The results found that the pre-cycle stage, the average value of students was 58.54 with classical learning completeness of $20.5 \%$. After learning to apply the picture media, in the first cycle, the average value was 67.70 with the classical completeness was $58.33 \%$. Furthermore, in the second cycle, the average value was 74.58 with $79.16 \%$ classical learning completeness. Then, continued in the third cycle the average value is 81.45 with classical learning completeness is $95.83 \%$. Thus, the skill of writing essays in the description of grade V students of SDN 09 Mattekko by applying picture media starting from the first cycle to the third cycle shows effective results. Therefore, the image media needs to be used as a reference by the teacher in learning to write essays in elementary schools, especially SDN 09 Mattekko, Palopo city.
\end{abstract}

Keywords: Description Descriptions, Image Media, Writing Skills

\begin{abstract}
Abstrak
Penelitian bertujuan mengetahui peningkatan keterampilan menulis karangan deskripsi yang diterapkan melalui media gambar pada siswa kelas V SDN 09 Mattekko kec. Bara Kota Palopo. Penelitian ini menggunakan pendekatan kuantitatif dan kualitatif dengan jenis Penelitian Tindakan Kelas (PTK) yang didesain melalui tiga siklus. Subjek penelitian, siswa-siswi Sekolah Dasar Negeri 09 Mattekko kelas V yang berjumlah 24 siswa. Teknik pengumpulan data yang digunakan, yaitu observasi, dokumentasi, dan tes. Data yang diperoleh dinalisis dengan menggunakan rumus statistik deskriptif (persentasi) untuk mengungkapkan secara deskriptif hasil penelitian. Selanjutnya, untuk membahas dan menjelaskan hasil penelitian yang bersifat kualitatif deskriptif maka digunakan teknik analisis reduksi data, penyajian data, dan penarikan kesimpulan. Hasil penelitian ditemukan bahwa tahap prasiklus, nilai rata-rata siswa adalah 58,54 dengan ketuntasan belajar klasikal 20,5\%. Setelah dilaksanakan pembelajaran menerapkan media gambar, pada siklus I nilai rata-rata adalah 67,70 dengan ketuntasan klasikal adalah 58,33\%. Selanjutnya, pada siklus II nilai rata-rata adalah 74,58 dengan nilai ketuntasan belajar klasikal $79,16 \%$. Kemudian, dilanjutkan pada siklus III nilai rata-rata adalah 81,45 dengan ketuntasan belajar klasikal adalah 95,83\%. Dengan demikian, keterampilan menulis karangan deskripsi siswa kelas V SDN 09 Mattekko dengan penerapkan media gambar dimulai dari siklus pertama sampai siklus ke-3 menunjukkan hasil yang efektif.
\end{abstract}




\section{8 | Idarliati}

Oleh karena itu, media gambar perlu dijadikan referensi oleh guru dalam kegiatan pembelajaran menulis karangan di sekolah dasar, khususnya SDN 09 Mattekko kota palopo.

Kata Kunci,: Keterampilan Menulis, Karangan Deskripsi, dan Media Gambar.

\section{PENDAHULUAN}

Pembelajaran Bahasa Indonesia merupakan salah satu mata pelajaran yang wajib disetiap sekolah yang ada di indonesia. Menurut Badan Standar Nasional Pendidikan dalam Ahmad Susanto (2003:245) mengungkapkan bahwa pembelajaran bahasa Indonesia diarahkan untuk menumbuhkan dan meningkatkan kemampuan peserta didik terhadap apresiasi hasil karya saatra manusia Indonesia dalam berkomunikasi dengan bahasa Indonesia yang baik dan benar, baik secara lisan maupun secara tertulis. Bahasa Indonesia merupakan bahasa resmi yang digunakan oleh bangsa Indonesia sebagai sebagai alat komunikasi. Bahasa Indonesia diartikan oleh Zulela (2013:3) bahwa bahasa adalah segala sesuatu yang harus dipelajari dan dikembangkan sebagai hasil budaya. Kemampuan berbahasa bagi manusia sangat diperlukan. Sebagai mahkluk sosial manusia perlu berinteraksi, berkomunikasi menggunakan bahasa sebagai media berkomunikasi baik secara lisan maupun tulisan.

Mata pelajaran bahasa indonesia kurang disenangi oleh sebagian siswa, khususnya dalam menulis. Kecenderungan ini biasanya berawal dari pengalaman belajar mereka yang memberikan kesan bahwa menulis itu sulit. Hal ini menyebabkan siswa kurang termotivasi dalam mengikuti pelajaran Bahasa Indonesia. Siswa kurang aktif menyampaikan ide dan gagasannya dan tidak antusias mengikuti pelajaran. Oleh karena itu, hasil menulis karangan siswa setelah mengikuti pelajaran tidak sesuai dengan KKMyang ditetapkan.

Berdasarkan hasil karangan deskripsi siswa kelas V SDN 09 Mattekko tampak bahwa keterampilan menulis karangan deskripsi siswa masih rendah. Dalam pengkajian materi, guru belum mampu menyajikan materi menulis secara menarik, inspiratif, dan kreatif. Hal tersebut diakibatkan siswa tidak terbiasa mengkaji secara langsung permasalahan yang hendak ditulis. pada hakikatnya kemampuan menulis siswa sangat bergantung pada penguasaan hal yang hendak ditulis. Hasil karangan siswa dikumpulkan kemudian dinilai tanpa dilakukan pembahasan karangan dan tata tulisan yang baik. Selain itu, hasil karangan peserta didik juga kurang memuaskan karena peserta didik belum mampu membuat paragraf yang baik, Peserta didik masih merasa kesulitan menyusun kata-kata menjadi sebuah kalimat, Rendahnya atau sedikitnya penguasaan kosakata yang dimiliki oleh peserta didik, Pilihan kata yang digunakan peserta didik kurang bervariasi, isi karangan masih berantakan dan tercampur dengan bahasa daerah dan 
bahasa gaul, penggunaan tanda baca masih banyak yang kurang, bahkan tidak ada tanda bacanya, dan Peserta didik masih mengalami kesulitan untuk menuangkan ide-ide dan pemikirannya kedalam bentuk tulisan. Dalam hal ini keterampilan menulis karangan perlu memdapatkan perhatian dan diajarkan. Karenanya dengan menulis seseorang bisa menyampaikan apa yang sedang dialaminya.

Menurut Tarigan (2013:1) keterampilan berbahasa terdiri atas empat komponen, yaitu keterampilan menyimak, keterampilan berbicara, keterampilan membaca, dan keterampilan menulis. dari keempat keterampilan tersebut keterampilan menulis menurut Byrne dalam Kundharu (2014:153) mengungkapkan bahwa keterampilan menulis pada hakikatnya bukan sekedar kemampuan menulis simbo-simbol grafis sehingga berbentuk kata, kata-kata disusun menjadi kalimat menurut peraturan tertentu, melainkan keterampilan menulis adalah kemampuan menuangkan buah pikiran kedalam bahasa tulis melalui kalimat-kalimat yang dirangkai secara utuh, lengkap, dan jelas sehingga buah pikiran tersebut dapat dikomunikasikan kepada pembaca dengan berhasil. keterampilan menulis menuntut kemampuan menggunakan pola-pola bahasa secara tertulis untuk mengungkapkan suatu gagasan. Keterampilan menulis ini mencakup berbagai kemampuan, misalnya kemampuan menggunakan unsurunsur bahasa yang tepat, kemampuan mengorganisasikan wacana dalam bentuk karangan, kemampuan menggunakan gaya bahasa yang tepat dan pilihan kata serta yang lainnya.

Keempat keterampilan itu merupakan satu kesatuan, tidak dapat pisahkan antara satu dengan lainnya. Kesalahan dalam tata penulisan menyebabkan kerancuan kalimat yang berujung pada kesalahan pola penalaran pembacanya (Rustan, 2016). Pengajaran Bahasa Indonesia khususnya pembelajaran keterampilan menulis perlu dilakukan sejak dini, yakni mulai tingkat Sekolah Dasar yang akan berguna sebagai landasan pada jenjang tingkat lanjut dan juga sebagai upaya untuk meningkatkan mutu penggunaan Bahasa Indonesia ini diarahkan untuk meningkatkan kemampuan siswa dalam berkomunikasi dengan Bahasa Indonesia yang dapat dilihat dari penguasaan empat keterampilan tersebut. Dalam hal ini keterampilan menulis karangan memang menjadi satu keterampilan berbahasa yang sangat sulit untuk dikuasai siswa. Hal ini disebabkan adanya dua unsur yang harus dikuasai oleh penulis, yaitu unsur bahasa, seperti ejaan, sruktur kalimat, kohesi, dan koherensi. Serta unsur non bahasa seperti yang dijadikan ide atau gagasan dalam sebuah tulisan yang meliputi pengetahuan dan pengalaman penulis. 


\section{0 | Idarliati}

Menulis merupakan salah satu keterampilan berbahasa yang digunakan untuk mengungkapkan pikiran atau gagasan, dan untuk menyampaikan pesan atau komunikasi melalui bahasa tulis sebagai medianya sehingga mudah untuk dipahami oleh pembaca. Asul Wiyanto (2014:1-2) mengungkapkan bahwa Kata menulis mempunyai dua arti. Pertama, menulis berarti mengubah bunyi yang dapat didengar menjadi tanda-tanda yang dapat dilihat. Bunyi-bunyi yang dapat diubah itu bunyi bahasa, yaitu bunyi yang dihasilkan oleh alat ucap manusia (mulut dan perangkat perlengkapannya: bibir, gigi, dan langit-langit). Bunyi bahasa itu sebenarnya menjadi lambang benda, perbuatan, sifat, dan lain-lain. Kedua, menulis mempunyai arti kegiatan mengungkapkan gagasan secara tertulis. Orang yang melakukan kegiatan ini dinamakan penulis dan hasil kegiatannya berupa tulisan yang bertujuan untuk dibaca orang lain agar gagasan yang disampaikan penulis dapat diterimah oleh pembaca. Pengertian menulis juga diartikan oleh Imron Rosidi (2009:2) menulis merupakan sebuah kegiatan menuangkan pikiran, gagasan, dan perasaan seseorang yang diungkapkan dalam bahasa tulis.

Menulis merupakan suatu kegiatan untuk mengungkapkan atau menyatakan pikiran dan perasaan dalam bentuk tulisan yang diharapkan dapat dipahami oleh pembaca dan berfungsi sebagai alat komunikasi tidak langsung, sedangkan menurut Widiyamartaya dalam Sukirman Nurdjan (2015:12) mengungkapkan bahwa mengarang atau menulis adalah keseluruhan rangkaian kegiatan seseorang mengungkapkan gagasan dan menyampaikan pesan melalui bahasa tulis kepada pembaca untuk dipahami tepat, seperti apa yang dimaksud oleh pengarang. Gagasan yang disampaikan adalah pesan yang ada dalam dunia batin yang hendak disampaikan kepada orang lain. Gagasan tersebut, seperti pengetahuan, pengamatan, pendapat, renungan, keinginan, perasaan, emosi dan sebagainya. Penyampaian atau penuturan gagasan tersebut disampaikan dalam bentuk penceritaan (narasi), pelukisan (deskripsi), pemaparan (eksposisi), dan pembahasan (argumentasi). Jadi menulis pada dasarnya suatu proses yang mengungkapkan gagasan melalui berpikir dan memanfaatkan bahasa sebagai sarana untuk menjelaskan kehendak atau keinginan penulis kepada pembaca.

Zainuddin (1992:97) mengungkapkan bahwa menulis dalam arti yang sederhana adalah merangkai-rangkai huruf menjadi kata atau kalimat. Adapun menulis yang disebut sebagai karangan ilmiah adalah mengungkapkan sesuatu yang ada dalam buah pikiran dengan kriteria tertentu. Pengungkapan buah pikiran harus berdasarkan data yang nyata atau berdasarkan ilmu pengetahuan. Akhadiyah Ahmad Rofi'uddin dan

\section{PiJIES: Pedagogik Journal of Islamic Elementary School}


Darmiyati Zuchdi (1999: 262) mengatakan bahwa menulis merupakan aktivitas mengekpresikan ide, gagasan, pikiran, atau perasaan ke dalam lambang-lambang kebahasaan atau bahasa tulis.

Menulis adalah suatu kegiatan atau aktivitas dari seseorang untuk menyampaikan suatu gagasan secara tidak langsung kepada orang lain dengan pembaca menggunakan lambang grafik yang dapat dipahami oleh penulis dan pembaca sehingga terjadi komunikasi tidak langsung antara penulis dan pembaca. Pengertian menulis juga diungkapkan oleh Subana, dan Sunarti (2000: 231) menyebutkan bahwa menulis atau mengarang merupakan kegiatan pengungkapan gagasan atau idenya secara tertulis.

Karangan deskripsi adalah jenis karangan yang menggambarkan sebuah peristiwa atau kejadian dengan sejelas-jelanya yang membuat pembaca seolah-olah mengalami kejadian tersebut. Karangan deskripsi merupakan salah satu jenis karangan yang harus dikuasai oleh siswa. Karangan ini sudah dapat diperkenalkan sejak SD kelas IV. Oleh karena itu, siapa pun yang menjadi guru mata pelajaran Bahasa Indonesia harus menguasai materi tentang karangan deskripsi. Suparno Muhammad Yunus (2006: 4-6) Kata deskripsi berasal dari kata latin describere yang berarti menggambarkan atau memerikan suatu hal. Dari segi istilah, deskripi adalah suatu bentuk karangan yang melukiskan atau memerikan suatu hal sejelasjelasnya sehingga pembaca seolah-olah menyaksikan atau mengalami sendiri. Menurut Finoza dalam Dalman (2015: 93) mengungkapkan bahwa deskripsi adalah bentuk tulisan yang bertujuan memperluas pengetahuan dan pengalaman pembaca dengan jalan melukiskan hakikat objek yang sebenarnya. Deskripsi ini bersal dari kata "descrebe" yang berarti menulis tentang, atau membeberkan hal, atau dengan kata lain deskripsi adalah suatu karangan yang digunakan penulis untuk memindahkan kesan-kesannya, memindahkan hasil pengamatan dan perasaannya, dan disajikan kepada pembaca. Mariskan mengemukakan bahwa deskripsi atau lukisan adalah karangan yang melukiskan kesan atau panca indra semata dengan teliti dan sehidup-hidupnya agar pembaca atau pendengar dapat melihat, mendengar, merasakan, menghayati, dan menikmati seperti yang dilihat, didengar, dirasakan, dan dihayati, serta dinikmati penulis. Keterampilan menulis merupakan kegiatan kompleks dimana saat terjadi pemrosesan informasi membutuhkan kerjasama dari kedua belahan otak siswa. Untuk dapat menstimulus kerja otak yang optimal diperlukan pengajaran dan pelatihan yang tepat misalnya dengan melakukan pengembangan model pembelajaran (Rustan, 2017).

Media adalah alat bantu yang digunakan untuk menyampaikan pelajaran kepada siswa agar apa yang disampaikan guru dapat dipahami oleh 


\section{2 | Idarliati}

siswa. Sukirman (2012: 27-28) Kata media berasal dari bahasa latin yang merupakan bentuk jamak dari kata medium yang secara harfiah berarti 'pengantar'. Secara bahasa media berarti pengantar pesan dari pengirim kepada penerima pesan. Menurut Anderson, media pembelajaran dalam media yang memungkinkan terwujudnya hubugan langsung antara karya seseorang pengembang mata pelajaran dengan para siswa. Sesuai dengan pendapat tersebut AECT dalam Nursalam (2013: 5) berpendapat bahwa media adalah segalah bentuk dan saluran yang dipergunakan untuk proses penyaluran pesan. Media juga diartikan sebagai segalah sesuatu yang dapat digunakan untuk menyalurkan pesan yang dapat merangsang pikiran, perasaan, perhatian, dan kemauan siswa untuk belajar. Atwi Suparman dalam pupuh Fathurrohman (2010: 5) mendefinisikan, media merupakan alat yang digunakan untuk menyalurkan pesan atau informasi dari pengirim pesan kepada penerimah pesan.

Pengertian tersebut dapat dipahami bahwa media pembelajaran adalah seperangkat alat yang digunakan untuk mempermudah kita dalam menangkap dan menerima pesan, atau media pembelajaran adalah alat, sarana, perantara, pengantar, dan penghubung untuk membawa pesan dan gagasan kepada penerima pesan.

Pembelajaran di sekolah, guru dapat menciptakan suasana belajar yang menarik perhatian peserta didik. Salah satu media yang dapat digunakan guru dalam upaya menarik perhatian peserta didik dalam mengarang adalah media gambar. Media gambar diberikan agar peserta didik dapat menceritakan sebuah peristiwa yang terdapat dalam gambar, melatih imajinasi peserta didik dalam mengembangkan sebuah karangan dengan melihat gambar. Penggunaan media gambar dalam pembelajaran menulis karangan deskripsi dimaksudkan untuk mengembangkan imajinasi dan daya nalar peserta didik.

Media gambar adalah bentuk gambar yang bersifat kongkret. Media gambar/ foto merupakan salah satu media pembelajaran yang amat dikenal dalam setiap kegiatan pembelajaran. Hal ini disebabkan kesederhanaannya, tampa memerlukan perlengkapan, dan tidak perlu diproyeksikan untuk mengamatinya. Selain sederhana dan mudah media gambar termasuk media yang mudah untuk didapatkan dan murah dari segi biayanya. Sesuai dengan pernyataan tersebut, Arif Sardiman dkk (1969: 69) mengungkapkan bahwa diantara media pendidikan, gambar/foto adalah media yang paling umum dipakai. Dia merupakan bahasa yang umum, yang dapat dimengerti dan dinikmati dimana-mana. Oleh karena itu, pepata cina mengatakan bahwa sebuah gambar berbicara lebih banyak daripada seribu kata. Media gambar adalah alat bantu yang digunakan guru dalam mengelolah pembelajaran yang 
bersifat kongkret. Menurut Riyanto ( 2002: 24) bahwa media gambar adalah symbol atau tanda yang memungkinkan terjadi sebuah komunikasi. Sedangkan media gambar merupakan media visual yang berbentuk dua dimensi yang memiliki bentuk bermacam-macam seperti potret, film, lukisan, dan slide Omar Hamalik ( 2004 : 95 ).

Dalam pembelajaran di sekolah dasar media gambar sangat baik di gunakan dan di terapkan dalam proses belajar mengajar sebagai media pembelajaran karena media gambar ini cenderung sangat menarik hati siswa sehingga akan muncul motivasi untuk lebih ingin menegtahui tentang gambar yang dijelaskan dan guru pun dapat menyampaikan materi dengan optimal melalui media gamabar tersebut.

\section{METODE}

Pendekatan yang digunakan dalam penelitian ini adalah pendekatan kualitatif dan kuantitatif. Adapun jenis penelitian yang digunakan adalah penelitian tindakan kelas (PTK). Penelitian tindakan kelas adalah jenis penelitian yang digunakan didalam kelas. Kunandar (2011: 45) mengungkapkan bahwa penelitian tindakan kelas adalah penelitian yang bertujuan untuk memperbaiki mutu disetiap pembelajaran didalam kelas. PTK ini juga dapat menjembatani kesenjangan antara teori dan praktek pendidikan. Menurut Cohen dan Monion dalam bukunya Sukidin, Basrowi, dan Suranto (2010:15) bahwa penelitian tindakan kelas mempunyai lima kategori fungsi yaitu 1) sebagai alat untuk memecahkan masalah yang dilakukan dengan diagnosis dalam situasi tertentu. 2) sebagai alat pelatihan dalam jabatan sehingga membekali yang bersangkutan dengan keterampilan, metode dan teknik mengajar yang baru, mempertajam kemampuan analisisnya dan mempertinggi kesadaran atas kelebihan dan kekurangan pada dirinya. 3) sebagai alat untuk mengenalkan pendekatan tambahan atau inovatif pada pengajaran. 4) sebagai alat untuk meningkatkan komunikasi antara guru dilapangan dan peneliti akademis, serta mempernaiki kegagalan penelitian tradisional. 5) sebagai alat untuk menyediakan alternatif atau pilihan yang lebih baik untuk mengantisifasi pendekatan yang lebih subjektif, impresiontik dalam memecahkan masalah dalam kelas. Muhadi (2011: 62) kelima kategori PTK ini merupakan sebuah alat untuk meningkatkan kinerja seorang guru dalam mengerjakan tugas-tugasnya.

Sesuai dengan jenis penelitian yang dipilih, maka penelitian ini menggunakan desain penelitian Kurt Lewin karena dianggap mudah yaitu menjelaskan bahwa ada hal yang harus dilakukan dalam proses penelitian yakni perencanaan, tindakan, observasi, dan refleksi. Pelaksanaan penelitian 


\section{4 | Idarliati}

tindakan adalah proses yang terjadi dalam proses satu lingkaran secara terus-menerus.

Lokasi penelitian adalah tempat yang digunakan dalam melakukan penelitian untuk memperoleh data. Penelitian ini dilaksanakan di SDN 09 Mattekko Kec. Bara Kota Palopo. 1) sumber data, dalam penelitian ini peneliti menggunakan data untuk mendukung penelitiannya yaitu data primer. 2) subjek penelitian, subjek penelitian ialah siswa siswi kelas V yang berjumlah 24 siswa terdiri dari 10 laki-laki dan 14 perempuan pada semester ganjil tahun ajaran 2017/ 2018.

Pengolahan data dilakukan setelah data terkumpul, selanjutnya dianalisis secara kuantitatif dan kualitatif. Untuk analisis kuantitatif digunakan analisis statistic deskriptif yaitu skor rata-rata dan persentase. Sedangakan analisis kualitatif diperoleh dari data melalui observasi aktivitas belajar siswa dan guru. Analisis tersebut dihitung menggunakan rumus statistik Suharsimi (2002 : 264) $\mathrm{X}=\frac{\sum X}{N}$ menjumlahkan semua nilai yang diperoleh siswa selanjutnya dibagi dengan jumlah siswa sehingga diperoleh nilai rata-rata, hasil tersebut kemudian diklasifikasikan kedalam bentuk penskoran nilai siswa dengan menggunakan kriteria standar penilaian. Anas Sudijono (2009:43) rumus mencari frekuensi $\mathrm{P}=\frac{\mathrm{F}}{\mathrm{N}} \times 100 \%$ target kategori tuntas $80 \%$ - $100 \%$ dan subyek $\leq 40 \%$ termasuk dalam kategori tidak tuntas.

\section{HASIL PENELITIAN}

Setelah peneliti menerapkan media gambar dalam menulis karangan deskripsi siswa kelas V SDN 09 Mattekko dapat diketahui bahwa aktivitas belajar siswa mengalami peningkatan. Hal ini dapat diketahui berdasarkan hasil observasi yang dilakukan pada setiap pertemuan mulai dari prasiklus, siklus I, siklus II, dan siklus III dapat digambar dalam diagram berikut ini.

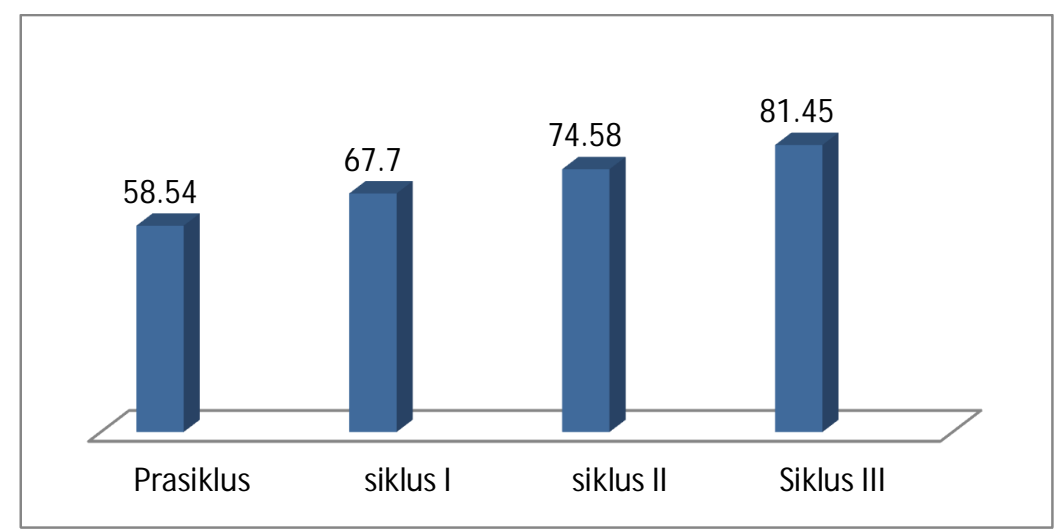

Diagram hasil tes eveluasi prasiklus, siklus I, siklus II, dan siklus III

PiJIES: Pedagogik Journal of Islamic Elementary School 
Berdasarkan diagram tersebut dapat dipahami bahwa data awal siswa dalam menulis karangan deskripsi belum memenuhi nilai KKM, alasan tersebut memotivasi peneliti untuk melakukan penelitian dengan menggunakan media gambar untuk meningkatkan keterampilan menulis karangan deskripsi siswa. Berdasarkan hasil diagram tersebut menunjukkan bahwa secara keseluruhan tes hasil belajar siswa mengalami peningkatan dari prasiklus sampai siklus III. Adapun hasil peningkatannya adalah pada prasiklus sebesar 58,54 meningkat menjadi 67,70 siklus I, Nilai rata-rata keterampilan menulis karangan siswa dari siklus I sebesar 67,70 meningkat menjadi 74,58 pada siklus II, pada siklus III nilai rata-rata siswa dari 74,58 meningkat menjadi 81,45. Jadi, penerapan media gambar dalam menulis karangan deskripsi siswa meningkat.

\section{PEMBAHASAN}

Dalam pembahasan, akan diuraikan hasil penelitian mengenai peningkatan keterampilan menulis karangan deskripsi menggunakan media gambar pada pelajaran bahasa Indonesia siswa kelas V SDN 09 Mattekko. Hasil yang diuraikan adalah data mengenai kemampuan awal siswa dalam pelajaran bahasa Indonesia, pelaksanaan tindakan penelitian dan ketercapaian kemampuan siswa dalam menulis karangan deskripsi. 1. Peningkatan keterampilan menulis karangan deskripsi pada siklus I Keterampilan siswa dalam menulis karangan deskripsi sebelum dilakukan tindakan penelitian terlihat masih rendah. Hasil tes prasiklus yang dilakukan kepada 24 siswa menghasilkan nilai rerata sebesar 58,54. Dalam proses belajar mengajar yang dilakukan partisipasi dan keaktifan siswa belum optimal. Hal ini terlihat dari hasil pengamatan pembelajaran menulis karangan deskripsi di kelas, hanya sebagian kecil siswa yang tampak memperhatikan gurunya, sementara yang lain sibuk dengan aktivitas mereka masing-masing yang sama sekali tidak berkaitan dengan proses pembelajaran. Ketika diberi tugas untuk membuat sebuah karangan mereka kesulitan untuk menuliskan gagasannya. Dari hasil tulisan mereka terdapat banyak kekeliruan misalnya: kata yang mereka gunakan tidak baku, tanda baca sering tidak digunakan dan penggunaan huruf kapital banyak mengalami kekeliruan. Hal yang tadi dikemukakan untuk menunjukan bahwa keterampilan siswa dalam menulis karangan deskripsi rendah dan perlu diadakan perbaikan dalam kondisi tersebut. 


\section{6 | Idarliati}

Data yang diperoleh dari hasil tes prasiklus dan hasil pengamatan pembelajaran, tindakan yang akan dilakukan pun diputuskan. Dipilihlah media gambar dalam pembelajaran menulis deskripsi yang diyakini mampu meningkatkan perhatian dan minat siswa, sehingga keterampilan menulis mereka akan meningkat. Sesuai dengan pendapat Purwanto dan Alim yang menyatakan bahwa penggunaan gambar untuk melatih anak menentukan pokok pikiran yang mungkin akan menjadi karangan. Tindakan kelas siklus I dilaksanakan dalam 4 kali pertemuan. Pertemuan pertama, kedua, ketiga masing-masing berlangsung selama 2 x 35 menit. Tindakan dilaksanakan, terlebih dahulu berkonsultasi tentang konsep tindakan disusun secara matang, mulai dari waktu pelaksanaan, skenario pembelajaran hingga perlengkapan pembelajaran yang diperlukan kepada guru kelas.

Tindakan yang dilakukan pertama yaitu menunjukkan media gambar pada siswa. Fungsi gambar tersebut dapat menarik perhatian siswa, juga berfungsi untuk membantu siswa dalam menemukan kata-kata sehingga dapat menyusun kalimat. Gambar yang digunakan pada setiap siklus merupakan gambar tentang keindahan alam. Gambar tersebut berkaitan dengan kehidupan siswa, sehingga siswa belajar dengan kehidupan yang ada disekitarnya. Peningkatan minat untuk mengikuti pembelajaran mulai terlihat dengan digunakannya media pembelajaran. Guru memerintahkan membuat satu kalimat berdasarkan gambar. Suasana kelas terlihat meriah. Sebagian besar siswa mengacungkan tangan bahkan ada yang sampai berdiri. Tampaknya, mereka mulai berani untuk menyampaikan idenya. Hal ini sesuai dengan pendapat Hamalik yang mengatakan bahwa pemakaian media pembelajaran dalam proses pembalajaran dapat membangkitkan keinginan dan minat yang baru, membangkitkan motivasi dan rangsangan kegiatan belajar, dan bahkan membawa pengaruh-pengaruh psikologis terhadap anak.

Setelah dilaksanakannya tindakan siklus I, peningkatan keterampilan menulis karangan siswa mengalami peningkatan dibandingkan pada saat kegiatan prasiklus. Hal ini dibuktikan dengan meningkatnya hasil rerata menulis karangan deskripsi siswa yang mengalami peningkatan. Nilai rerata menulis siswa pada kegiatan pra siklus sebesar 58,54 meningkat menjadi 67,70 siklus I. 2. Peningkatan keterampilan menulis karangan deskripsi pada siklus II, Tindakan Kelas siklus II dilaksanakan dalam 4 kali pertemuan, yaitu 2 x 35 menit tiap pertemuan. Kegiatan perencanaan siklus II, terlebih dahulu konsep tindakan mulai dari waktu pelaksanaan sampai instrumen penelitian disusun dan dipersiapkan dengan baik. Pada pertemuan pertama siklus kedua, siswa berlatih membuat karangan deskripsi secara sederhana. Selain itu, siswa berlatih menganalisis kesalahan yang dilakukan dalam menulis 
karangan deskripsi. Media gambar yang digunakan dalam siklus ini bertemakan keindahan alam. Siswa mengamati gambar yang dibagikan. Guru memberi kesempatan pada siswa untuk menentukan tema dan menentukan judul sesuai gambar. Siswa terlihat aktif, hampir semua siswa ingin menyampaikan gagasannya. Guru memberi kesempatan beberapa siswa untuk menetukan judul karangan sesuai gambar tersebut. Setelah menentukan judul, guru memberi kesempatan pada salah satu siswa untuk membuat kerangka karangan.

Berdasarkan kerangaka karangan yang telah dibuat, guru memberi contoh cara mengembangkan kerangaka karangan tersebut menjadi karangan yang utuh. Guru melaksanakan proses pembelajaran dengan pendekatan melakukan pembimbingan kepada siswa yang mengalami kesulitan. Setelah penjelasan dirasa cukup, siswa diminta untuk membuat karangan deskripsi sederhana. Setelah latihan membuat karangan selesai, sisiwa diminta untuk membacakan karangannya. Hal ini bertujuan agar siswa berlatih berani dan percaya diri untuk maju kedepan kelas membacakan hasil karangan. Selain itu, juga melatih siswa untuk menghargai siswa yang sedang berbicara di depan. Hal tersebut dapat memotivasi siswa yang lain untuk berani maju.

Berdasarkan data perolehan nilai tes keterampilan menulis karangan deskripsi yang telah disajikan, terlihat adanya peningkatan kemampuan keterampilan menulis yang signifikan dari sebelum dilakukannya tindakan sampai setelah dilakukannya tindakan pada siklus II. Hasil tes keterampilan menulis karangan deskripsi setelah dilaksanakannya pembelajaran menggunakan media gambar, terus mengalami peningkatan. Nilai rata-rata keterampilan menulis karangan siswa dari siklus I sebesar 67,70 meningkat menjadi 74,58 pada siklus II . 3. Peningkatan keterampilan menulis karangan deskripsi pada siklus III, Penggunaan media gambar menunjukkan keefektipan siswa dalam meningkatkan kemampuan menulis karangan deskripsi. Pelaksanaan penelitian tindakan yang dilakukan selama tiga siklus dengan menggunakan media gambar dapat meningkatkan keterampilan menulis karangan deskripsi siswa.

Kondisi awal nilai rerata menulis karangan deskripsi sebesar 58,54. Peningkatan rata kelas nilai siswa dalam menulis karangan deskripsi setelah dilakukan prasiklus mengalami peningkatan pada siklus I dengan nilai rerata dari 58,54 meningkat menjadi 67,70, dari siklus I kesiklus II meningkat menjadi 74,58 dan pada siklus III nilai rata-rata siswa dari 74,58 meningkat menjadi 81,45. Kemudian hasil tes menulis karangan deskripsi yang diperoleh siswa menunjukan ketepatan dalam menentukan tema dan judul sesuai dengan gambar, kemampuan menyusun kerangka karangan, 


\section{8 | Idarliati}

kesesuaian antara karangan dengan gambar, struktur isi, penggunaan ejaan dan tanda baca. Dilakukannya tindakan berupa pelaksanaan rangkaian kegiatan pembelajaran menulis karangan deskripsi menggunakan media gambar siswa meningkat dari waktu kewaktu.

Berdasarkan hasil penelitian tampak bahwa penggunaan media gambar memiliki pengaruh dalam meningkatkan keterampilan menulis karangan deskripsi siswa kelas V SDN 09 Mattekko Kecamatan Bara Kota Palopo. Asnawir dan Basyiruddin Usman (2002:50) dalam bukunya yang berjudul Media Pembelajaran menyatakan bahwa kelebihan Media Gambar adalah (1) lebih kongkret dan realistis dalam memunculkan pokok masalah, jika dibandingkan dengan bahasa verbal (2) dapat mengatasi ruang dan waktu (3) dapat mengatasi keterbatasan mata (4) memperjelas masalah dalam bidang apa saja, dan dapat dipergunakan untuk semua orang tampa memandang umur. Penerapan media gambar tersebut memberikan kontribusi positif terhadap proses pembelajaran, sehingga memudahkan guru dalam menyampaikan materi.

Berdasarkan uraian tersebut, dapat dipahami bahwa peningkatan keterampilan menulis karangan deskripsi siswa dalam proses pembelajaran disebabkan oleh kreativitas guru dalam mengelola kondisi kelas. Media yang diterapkan guru dapat menarik perhatian siswa sehingga hasil menulis karangan deskripsi yang didapatkan pada setiap siklus selalu memperlihatkan peningkatan.

Berdasarkan nilai hasil menulis siswa yang diperoleh dapat dikatakan bahwa pada saat diterapkan media gambar dalam pembelajaran memberikan dampak positif. Indikator keberhasilan dalam penilaian ini tercapai, dalam hal ini 24 siswa telah mencapai nilai $\geq 75$, maka penelitian ini dihentikan sampai pada siklus III. Hal ini menunjukkan bahwa keterampilan menulis karangan deskripsi siswa kelas V SDN 09 Mattekko Kecamatan Bara Kota Palopo meningkat pada saat media gambar diterapkan.Pada bagian ini, alur penjelasannya hampir sama dengan pembahasan rumusan masalah pertama.

\section{PENUTUP}

Kesimpulan

Berdasarkan hasil penelitian yang diperoleh dan dianalisis maka dapat disimpulkan bahwa penggunaan media gambar dapat meningkatkan keterampilan menulis karangan deskripsi siswa. Hal itu terlihat dari antusias siswa dalam proses pembelajaran dan hasil membuat karangan deskripsi di setiap siklusnya meningkat. Kegiatan belajar siswa lebih komunikatif dan menyenangkan. Dalam pembelajaran menulis karangan deskripsi sebelum 
mengguanakan media gambar siswa terlihat pasif, kurang termotivasi, dan menganggap menulis itu menjenuhkan. Dengan penggunaan media gambar dalam proses pembalajaran siswa menjadi lebih aktif, dapat menuangkan gagasannya dengan baik, menulis dengan kaidah penulisan yang benar, dan lebih antusias dalam mengikuti pembelajaran.

Penggunaan media gambar dapat meningkatkan keterampilan menulis karangan deskripsi pada siswa kelas V SDN 09 Mattekko. Peningkatan keterampilan menulis pada prasiklus sebesar 58,54, siklus I sebesar 67,70, siklus II sebesar 74,58 dan siklus III sebesar 81,45.

Penelitian tindakan yang dilaksanakan sudah memenuhi kriteria keberhasilan yang ditetapkan, yaitu siswa memperoleh nilai 70 sehingga pelaksanaan penelitian tindakan dapat disimpulkan bahwa penggunaan media gambar dapat memberikan dampak yang positif, karena dengan media gambar dalam pembelajaran dapat meningkatkan keterampilan siswa dalam menulis karangan deskripsi.

Saran

Beberapa saran yang dapat disampaikan berdasarkan hasil penelitian ini adalah sebagai berikut: 1, Bagi guru, guru dapat menggunakan media gambar sebagai bahan pembaharuan terhadap pembelajaran bahasa Indonesia khususnya dalam keterampilan menulis karangan. Dengan media gambar, kemampuan siswa terhadap menulis dapat dikembangkan dengan baik. 2, Bagi siswa, hasil baik yang sudah dicapai harus ditingkatkan lagi, dan siswa yang masih mengalami kesulitan dalam menulis harus memperbanyak latihan menulis. 3. Bagi sekolah, pembelajaran dengan menggunakan media gambar perlu didukung dan dikembangkan. Salah satunya dengan menyediakan gambar-gambar yang lebih banyak dan bervariasi.Pada bagian ini menyajikan ringkasan dari uraian mengenai hasil dan pembahasan, mengacu pada tujuan penelitian. Berdasarkan kedua hal tersebut dikembangkan pokok-pokok pikiran baru yang merupakan esensi dari temuan penelitian.

Selanjutnya dikemukakan saran. Saran disusun berdasarkan temuan penelitian yang telah dibahas. Saran dapat mengacu pada tindakan praktis, pengembangan teori baru, dan/ atau penelitian lanjutan

\section{DAFTAR PUSTAKA}

Ahmad Rofi'uddin dan Darmiyati Zuhdi 1998/1999, Pendidikan Bhasa dan Sastra Indonesia di Kelas Tinggi. Jakarta: Departemen Pendidikan dan Kebudayaan. 


\section{0 | Idarliati}

Arikunto, Suharsimi. 2002, Dasar-dasar Evaluasi Pendidikan, Ed. Revisi. III; Jakarta: Bumi Aksara.

Asnawir dan Basyiruddin Usman,2002, Media Pembelajaran, Cet I; Jakarta Selatan, Ciputat Pers.

Dalman, 2015, Keterampilan Menulis edisi I, Cet IV; Jakarta: Rajawali.

Fathurrohman Pupuh, Sobry Sutikno, 2010, Strategi Belajar Mengajar Melalui Konsep Umum dan Konsep Islami, Cet I; Bandung PT Refika Aditama.

Finoza Lamuddin, 2005, Komposisi Bahasa Indonesia untuk Mahasiswa non Jurusan Bahasa, Cet XI; Jakarta, Diksi Insan Mulia.

Hamalik, Oem ar. 2004, Media Pendidikan, Jakarta:Universitas Terbuka.

Kunandar, 2011, Langkah Mudah Penelitian Tindakan Kelas Sebagai Pengembangan Profesi Guru, Cet VII: Jakarta ; PT Raja Grafindo Persada.

Muhadi, 2011, Penelitian Tindakan Kelas, Yogyakarta, Shira Media

Nurdjan, Sukirman, 2015, Cara Kreatif Menulis Karya Ilmiah, Cet; Palopo: Aksara Timur.

Nursalam Mochamad, 2013, Pengembangan Media Bimbingan dan Konseling, Cet I; Jakarta Barat, Akademia Permata.

Riyanto, 2002, Strategi Pembelajaran Berorientasi Standar Proses Pendidikan, Jakarta: Kencana.

Rustan, E. (2016). Analisis Penggunaan Bahasa Indonesia Laras Hukum Pada Putusan Perkara Ekonomi Syariah Pengadilan Agama Makassar. Al Amwal, I(2), 166-176.

Rustan, E. (2017). Learning Creative Writing Model Based on Neurolinguistic Programming. International Journal of Language Education and Culture Review, 3(2), 13-29. https:/ / doi.org/ 10.21009/ IJLECR.032.02

Rosidi Imron, 2009, Menulis Siapa Takut?, Cet I; Yogyakarta: Kanisius.

Saddhono Kundharu dan Slamet. 2014. Pembelajara Keterampilan Berbahasa Indonesia, Cet. I : Yogyakarta; Graha Ilmu.

Sadiman Arif dkk., 1996, Media Pendidikan Pengertian, Pengembangan dan Pemanfaatannya, Cet IV; Jakarta: PT.RajaGrafindo Persada.

Sudijono Anas, 2007. Pengantar Statistik Pendidikan, Ed. I; Jakarta: Raja Grafindo Persada.

Sukidin, Basrowi, Suranto. 2010. Menejemen Penelitian Tindakan Kelas, Cet, IV: Insan Cendekia.

Sukirman, 2012, Pengembangan Media Pembelajaran Cet.I; Yogyakarta, PT Pustaka Insan Madani.

Susanto Ahmad, 2014, Teori Belajar dan Pembelajaran di Sekolah Dasar, Cet.II; Jakarta: Kencana. 
Upaya Meningkatkan Keterampilan Menulis ... |71

Tarigan, G.H, 2013, Menulis Sebagai Suatu Keterampilan Berbahasa, Bandung: CV. Angkasa.

Wiyanto, Asul, 2004, Terampil Menulis Paragraf, cet; Jakarta: Grasindo.

Yunus, Mohammad Suparno, 2006, Keterampilan Dasar Menulis, Jakarta: Universitas Terbuka.

Zainuddin, 1992, Materi Pokok Bahasa dan Sastra Indonesia Cet I; Jakarta: Rineka Cipta.

Zulela. 2013. pembelajaran Bahasa Indonesia, Apresiasi Sastra di Sekolah Dasar, Cet,II: Bandung; PT Remaja Rosdakarya. 
72 | Idarliati

Halaman ini sengaja dikosongkan

PiJIES: Pedagogik Journal of Islamic Elementary School 